OPEN ACCESS

Edited by:

Jose Angel Alvarez Perez, Universidade do Vale do Itajaí, Brazil

Reviewed by:

Erica A. G. Vidal,

Federal University of Paraná, Brazil

Ángel F. González,

Institute of Marine Research, Higher Council for Scientific Research (CSIC),

Spain

*Correspondence:

Roger Villanueva

roger@icm.csic.es

tORCID

Roger Villanueva orcid.org/0000-0001-8122-3449

Vladimir V. Laptikhovsky orcid.org/0000-0001-6965-8327

Stuart B. Piertney orcid.org/0000-0001-6654-0569 Fernando Ángel Fernández-Álvarez orcid.org/0000-0002-8679-7377

Martin A. Collins

orcid.org/0000-0001-7132-8650

Jonathan D. Ablett

orcid.org/0000-0002-7277-1934

Alejandro Escánez

orcid.org/0000-0001-6956-2974

Specialty section:

This article was submitted to Deep-Sea Environments and Ecology, a section of the journal

Frontiers in Marine Science

Received: 11 May 2020

Accepted: 30 October 2020

Published: 20 November 2020

Citation:

Villanueva R, Laptikhovsky W. Piertney SB, Fernández-Álvarez FÁ, Collins MA, Ablett JD and Escánez A (2020) Extended Pelagic Life in a Bathybenthic Octopus.

Front. Mar. Sci. 7:561125. doi: 10.3389/fmars.2020.561125

\title{
Extended Pelagic Life in a Bathybenthic Octopus
}

\section{Roger Villanueva ${ }^{1 * t}$, Vladimir V. Laptikhovsky ${ }^{2+}$, Stuart B. Piertney ${ }^{3 \dagger}$, Fernando Ángel Fernández-Álvarez ${ }^{1,4 t}$, Martin A. Collins ${ }^{5 \dagger}$, Jonathan D. Ablett6t and Alejandro Escánez ${ }^{7+}$}

\begin{abstract}
1 Institut de Ciències del Mar, CSIC, Barcelona, Spain, ${ }^{2}$ Cefas, Lowestoft, United Kingdom, ${ }^{3}$ School of Biological Sciences, University of Aberdeen, Aberdeen, United Kingdom, ${ }^{4}$ Ryan Institute and School of Natural Sciences, National University of Ireland, Galway, Ireland, ${ }^{5}$ British Antarctic Survey, NERC, Cambridge, United Kingdom, ${ }^{6}$ Department of Life Sciences, Natural History Museum, London, United Kingdom, ${ }^{7}$ Departamento de Biología Animal, Edafología y Geología, Facultad de Biología, Universidad de La Laguna, Tenerife, Spain
\end{abstract}

Planktonic stages of benthic octopuses can reach relatively large sizes in some species, usually in oceanic, epipelagic waters while living as part of the macroplankton. These young octopuses appear to delay settlement on the seabed for an undetermined period of time that is probably longer than for those octopus paralarvae living in coastal, neritic waters. The reason for this delay is unknown and existing information about their biology is very scarce. Here we report on the presence of juvenile and subadult forms of the bathybenthic octopus Pteroctopus tetracirrhus in oceanic waters of the South and North Atlantic and its association with the pyrosomid species Pyrosoma atlanticum, apparently used by the octopus as a refuge or shelter. The relatively large size of the $P$. tetracirrhus living in oceanic waters as the individuals reported here, together with the morphological characteristics of this bathybenthic species including its gelatinous body, minute suckers embedded in swollen skin and the deep interbrachial web, indicates that $P$. tetracirrhus may be considered a model of a transitional octopus species that is colonizing the pelagic environment by avoiding descending to the bathyal benthos. This process seems to occur in the same way as in the supposed origin of the ctenoglossan holopelagic octopods of the families Amphitretidae, Bolitaenidae, and Vitreledonellidae, which have arisen via neoteny from the planktonic paralarval stages of benthic octopuses.

Keywords: Mollusca, Cephalopoda, Octopoda, planktonic larvae, mesopelagic zone

\section{INTRODUCTION}

Cephalopods are highly mobile molluscs, occupying diverse marine habitats and exhibiting different lifestyles. Benthic octopuses display two modes of life. Firstly, there are holobenthic species that produce relatively few and large eggs resulting in well-developed hatchlings that externally resemble the adults and rapidly adopt the benthic habitat and mode of life of their parents. Second, there are merobenthic octopus species that are characterized by the production of numerous small eggs that hatch into planktonic, swimming hatchlings that have been termed paralarvae (Young and Harman, 1988). These planktonic octopuses have few suckers and a transparent musculature, live in the water column from a few weeks to half a year depending on the species and temperature, 
and occupy ecological niches distinct from those of the adults before their definitive settlement on the seabed (Villanueva and Norman, 2008). Most planktonic octopuses can be considered as mesoplankton being between 0.2 and $20 \mathrm{~mm}$ total length (Harris et al., 2000). However, in some species, individuals reach relatively larger sizes, usually in oceanic, epipelagic waters so form part of the macroplankton $(2-20 \mathrm{~cm})$. These young octopuses appear to delay settlement on the seabed for an undetermined period of time that is probably longer than for paralarvae living in coastal, neritic waters. The reason for this delay is unknown and the existing information about their biology is very scarce. These large octopus paralarvae have been called "extended pelagic stages" by Rees (1954) and "superparalarvae" by Strugnell et al. (2004) and have been suggested to be octopuses that delay settlement on the seabed due to the absence of suitable bottom habitat such as shallow, neritic areas. Thus, relatively large individuals of at least 10 species of benthic octopuses have been collected or observed as part of the macroplankton, using plankton nets, light traps, and ROVs in coastal and oceanic waters (see Table 6 in Villanueva and Norman, 2008; Carrasco et al., 2012; Salman, 2012; Crespi-Abril et al., 2014; Roper et al., 2015). The largest individuals attain $25 \mathrm{~mm}$ in mantle length (ML) in Octopus rubescens (Young, 1972, as Octopus sp.) and $127 \mathrm{~mm}$ total length (TL) in Macrotritopus sp. (Brower, 1981).

An intriguing question is how these typically bottom-dwelling animals can remain as part of the plankton for long periods, especially considering subadult and adult octopuses are relatively poor swimmers. As the heavier arm crown grows notably in relation to the propulsive mantle cavity during the planktonic stage, jet-swimming abilities gradually reduce, ending with the settlement period when animals become benthic (Villanueva et al., 1997). Extended jet propulsion in adult shallow water benthic octopus forms such as Octopus vulgaris can result in cardiac arrest as the rise in internal mantle pressure renders the circulatory system incapable of returning blood to the hearts, inducing an oxygen debt and making jet propulsion a non-viable means of regular transport (Wells et al., 1987). Along with other factors, it is probable that these physiological limits determine that subadult and adult benthic octopuses are not capable of living as part of the megaplankton (size $20-200 \mathrm{~cm}$ ) and probably influence the maximum size of their planktonic stages. In fact, Thiel and Gutow (2005) listed five species of benthic octopuses rafting on macroalgae that may be taking advantage of this as both a means of passive transport and/or as an energy-saving method in addition to being an epipelagic structure that acts as a potential prey aggregator.

The paucity of information on the extended pelagic life in benthic octopuses prompts many questions about which part of the population is involved in this extended pelagic period and the advantages it may represent for the species dispersal. As far as we are aware, no symbiotic association of benthic octopuses with other animals in the water column has been recorded. Here we report on the presence of juvenile and subadult forms of the bathyal octopus Pteroctopus tetracirrhus (Delle Chiaje, 1841) in open, oceanic waters of the South and North Atlantic and its possible association with pyrosomids.

\section{MATERIALS AND METHODS}

Two individuals morphologically resembling the bathybenthic octopus Pteroctopus tetracirrhus were collected during oceanographic cruises made in 2015 and 2018 in the Atlantic Ocean. The first individual (cat. num. ICMC000193) was an immature female $25 \mathrm{~mm}$ mantle length (ML) measured after fixation (the specimen measured $28 \mathrm{~mm} \mathrm{ML}$ and weighted $15 \mathrm{~g}$ soon after capture). The octopus was found recently dead inside a Pyrosoma atlanticum colony, measuring $121 \mathrm{~mm}$ in total colony length, with $23 \mathrm{~mm}$ external diameter and $14 \mathrm{~mm}$ internal diameter of the hollow cavity of the colony (measured fresh soon after capture) (Figure 1). Both organisms were frozen at $-20^{\circ} \mathrm{C}$ after capture, during a oceanographic cruise on board the Spanish R/V Hespérides, using a Mesopelagos midwater trawl designed to sample mesopelagic fauna (see net and cruise details in Olivar et al., 2017). The specimens were collected at St. PEL12N on 27 April 2015 at $25^{\circ} 24^{\prime} \mathrm{N}, 17^{\circ} 23^{\prime} \mathrm{W}$ fishing between 0 and $800 \mathrm{~m}$ depth, net towed at $4.6 \mathrm{~km} \mathrm{~h}^{-1}$, opened from 21:09 to 22:56 h above depth of 3,093 m, south Canary Islands. In the laboratory, the specimen of $P$. tetracirrhus was defrosted, a fragment of the mantle was preserved in $96 \%$ ethanol for molecular studies and the remaining body was fixed in $4 \%$ formaldehyde and transferred to $70 \%$ ethanol before measurements were obtained (Supplementary Table S1). A second immature female individual (cat. num. NHM-UK 20200243) of $P$. tetracirrhus was sampled on board RRS James Clark Ross, St. $83 / 1$ on 7 April 2018 at $16^{\circ} 04^{\prime} \mathrm{S}, 5^{\circ} 42^{\prime} \mathrm{W}$ above depth of 793-869 m, near St Helena Island. An opening and closing RMT8 net was towed at $3.7-4.6 \mathrm{~km} \mathrm{~h}^{-1}$, from 03:01 to 03:49 h, opened between depths of 200 and $400 \mathrm{~m}$. From the specimen (ML $33 \mathrm{~mm}$, total length $110 \mathrm{~mm}$ ) a fragment of the arm was preserved in $96 \%$ ethanol for molecular studies and the remaining body was fixed in $4 \%$ formaldehyde and then transferred to $70 \%$ ethanol before measurements were taken. The external morphology of these mesopelagic P. tetracirrhus individuals collected by midwater trawl was compared with larger, bottom dwelling individuals of the same species. A total of 7 males ( $76 \pm 14 \mathrm{~mm} \mathrm{ML}$, range $56-96 \mathrm{~mm} \mathrm{ML}$ ) and 5 females $(81 \pm 16 \mathrm{~mm} \mathrm{ML}$, range from 60 to $105 \mathrm{~mm} \mathrm{ML})$ from the Biological Reference Collections (CBR) of the Institut de Ciències del Mar (ICM-CSIC, Barcelona, Spain) and collected by means of bottom trawl at depths ranging from 87 to 576 $\mathrm{m}$ in NW Mediterranean, were examined (Supplementary Table S1). From all individuals the mantle length (ML), total length (TL), Arm length ( $\mathrm{AL})$, and respective total length index (TLI) and mantle arm index (MAI) was obtained. In addition, the sucker diameter (SD), average arm sucker count (AASC), maximum web depth (WD max.) and web depth index (WDI) were obtained from both mesopelagic individuals. Measurements and indices were according to Roper and Voss (1983) and Toll (1988).

In order to generate DNA barcodes to facilitate species identification, total genomic DNA was extracted using the Qiagen DNeasy blood and tissue kit according to the manufacturer's instructions. To ensure the species identification of the samples, an additional mature female specimen of $P$. tetracirrhus collected 

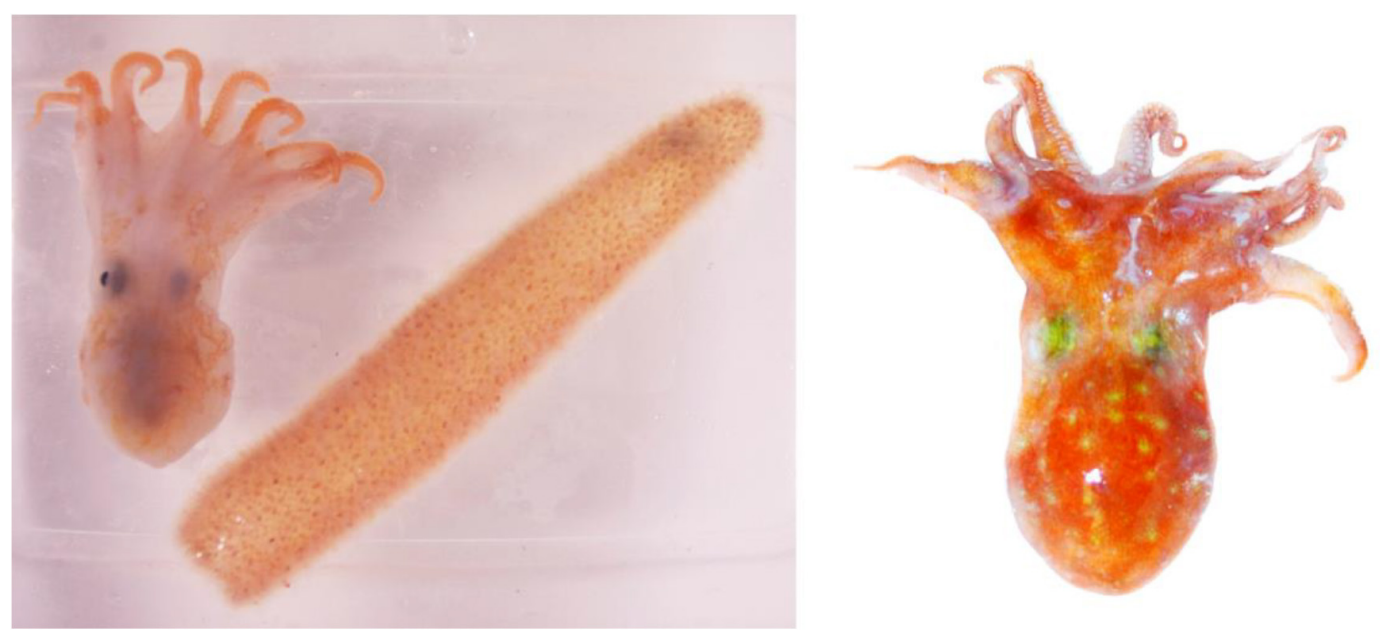

FIGURE 1 | Pteroctopus tetracirrhus individual $25 \mathrm{~mm} \mathrm{ML} \mathrm{(28} \mathrm{mm} \mathrm{ML} \mathrm{measured} \mathrm{fresh)} \mathrm{and} \mathrm{the} \mathrm{Pyrosma} \mathrm{atlanticum} \mathrm{colony} \mathrm{inside} \mathrm{of} \mathrm{which} \mathrm{it} \mathrm{was} \mathrm{found} \mathrm{after}$ capture, south Canary Islands, North Atlantic. Photo from Victor M. Tuset (left). P. tetracirrhus individual $33 \mathrm{~mm}$ ML captured in waters of St Helena Island, South Atlantic. Photo from Vladimir Laptikhovsky (right).

between 416 and 576 m depth off Palamós, NW Mediterranean, was also included (specimen ICMC000341, Supplementary Table S1). A partial fragment of the mitochondrial DNA cytochrome $c$ oxidase subunit 1 was PCR amplified using the primers LCO1490 5'-GGTCAACAAATCATAAAGATATTGG$3^{\prime}$ and HCO2198 5'-TAAACTTCAGGGTGACCAAAAAATCA3' (Folmer et al., 1994). Amplicons were purified using the Qiagen PCR purification kit according to manufacturer's instructions, then sequenced using the BigDye Terminator v3.1 (ABI) cycle sequencing protocol. Resultant electropherograms were examined using MEGA7 (Kumar et al., 2016).

\section{RESULTS}

Morphological and molecular analyses of both mesopelagic octopus individuals collected confirmed they belong to the bathybenthic species Pteroctopus tetracirrhus. Both individuals were collected at night using pelagic nets and were sexually immature females with the typical orange color skin found in fresh individuals of this species and with two elongate papillae over each eye. In the smaller individual (25 mm ML) its external morphology showed relatively short arms with MAI and TLI of 76 and 41, respectively (Supplementary Table S1 and Figure 2), with WD max. of $17 \mathrm{~mm}$ and WDI of 55, suggesting a juvenile octopus form. The individual reached $1.4 \mathrm{~mm} \mathrm{SD}$ and an AASC of 108 . The second and larger specimen (33 mm ML) had relatively larger arms, with MAI and TLI of 41 and 30, respectively, nearly reaching the adult octopus external body proportions in arm length vs. mantle length (Supplementary Table S1 and Figure 2) and can be considered as a sub-adult form due to it being sexual immature. The individual also possessed a deep web (WD max. $38 \mathrm{~mm}$; WDI, 47) and reached $2 \mathrm{~mm} \mathrm{SD}$ and an AASC of 146. A total of 658 base pairs were unambiguously resolved for the three samples. The three sequences were identical and were uploaded to NCBI under the accession number MT415947.

\section{DISCUSSION}

The fourhorn octopus, $P$. tetracirrhus, is a medium size octopus species reaching $850 \mathrm{~g}$ in weight that inhabits muddy substrates of the lower continental shelf and upper slope of the Eastern Atlantic, primarily between 200 and $500 \mathrm{~m}$, with adult forms reaching $750 \mathrm{~m}$ depth (Mangold-Wirz, 1963; Quetglas et al., 2009; Laptikhovsky et al., 2014; Norman et al., 2014; Escánez et al., 2019) and paralarvae at 800-1,000 m depth (Lo Bianco, 1903). The above results show the capacity for both juvenile and subadult form of this species to live in open, oceanic waters. Certain morphological characters of this benthic species may facilitate its movements far from the sea bottom, enabling it to favor arm-web, medusoid contractions over the more energetically expensive jet-swimming locomotion. These characters are their loose and soft, semigelatinous skin and musculature, minute suckers and the relatively short arms with a deep interbrachial web, as deep as $47-55 \%$ of arm length in the pelagic individuals examined here, decreasing to $40 \%$ in benthic individuals (Norman et al., 2014). However, prior to this study, only paralarvae of this species had been found in the water column and most biological studies of the species have been carried out using individuals collected by bottom trawl (Mangold-Wirz, 1963; Quetglas et al., 2009; Laptikhovsky et al., 2014). Hatchlings of $P$. tetracirrhus are planktonic, as laboratory fresh spawned eggs of the species are 7-8 $\mathrm{mm}$ in egg length (Boletzky, 1981) and an individual of $14 \mathrm{~mm}$ total length was collected between 800 and 1,000 m depth (Lo Bianco, 1903, as Scaeurgus tetracirrhus) and a second specimen $1.8 \mathrm{~mm}$ ML was reported over the shelf break (Lefkaditou et al., 2005), both from the Mediterranean Sea. 

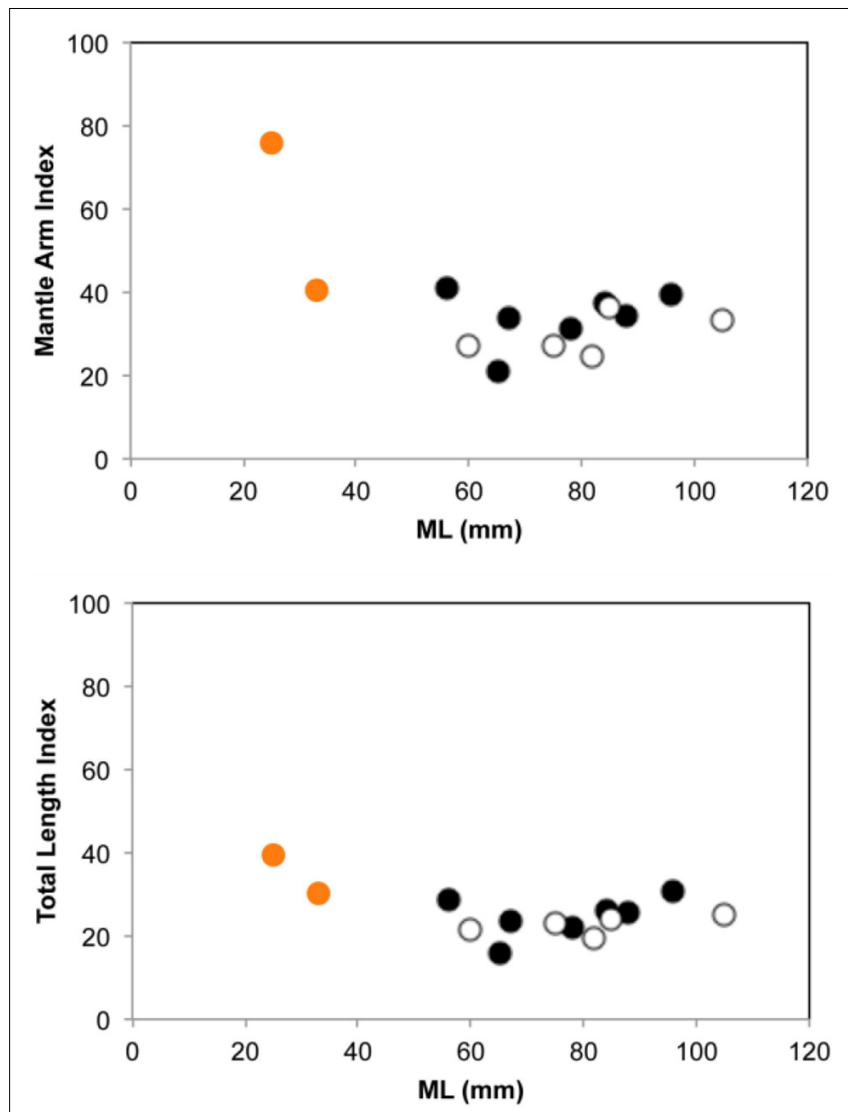

FIGURE 2 | Mantle arm index (up) and Total length index (down) in 14 individuals of Pteroctopus tetracirrhus measured after fixation. Black circles, males; white circles, females; orange circles, juvenile and sub-adult individuals of 25 and $33 \mathrm{~mm} \mathrm{ML}$, respectively, collected during present study.

The finding of a putative symbiotic association between $P$. tetracirrhus and the colonial pelagic tunicate Pyrosoma atlanticum is of interest. Apparently, the octopus might use the cylindrical pyrosomid colony as a refuge or shelter in a similar way as benthic octopuses commonly use hard structures and substrates on the sea bottom (Hanlon and Messenger, 2018). For $P$. tetracirrhus there might be some advantages in taking refuge inside the pryrosomid colony. Pyrosoma atlanticum is a species forming dense aggregations, reaching up to 41 colonies $\mathrm{m}^{-3}$ (Drits et al., 1992) that carry out diel vertical migrations from the surface to maximum depth strata of 800-1,000 m (Perissinotto et al., 2007; Henschke et al., 2019). In addition to free, energy-saving transport in the water column, the physical protection of $P$. atlanticum when used as refuge might be increased by the orange color of both the pyrosomid and the skin of $P$. tetracirrhus (see Figure 1), helping camouflage from possible predators. Moreover, crustacean groups such as hyperiid amphipods (Trégouboff and Rose, 1957) and penaeid shrimps (Lindley et al., 2001) have also been found inside pyrosomid colonies. Considering that crustaceans represent the most important prey items in subadult and adult P. tetracirrhus (Quetglas et al., 2009) it is possible that other invertebrates associated with pyrosomids also provide potential prey for the young octopus. It is possible that drag forces in the net during towing created a high hydrodynamic pressure and caused the $P$. tetrachirrus specimen to enter the pyrosma colony. Therefore, confirmation of this association between octopus and pyrosoma would be desirable in future observations.

Holopelagic octopod species that complete their life cycle in the water column, have also been reported as associating with gelatinous zooplankton. For example Ocythoe tuberculata (Hardwick, 1970; Okutani and Osuga, 1986) and Argonauta sp. (Banas et al., 1982) are known to live inside salps, whilst species such as Haliphron atlanticus and Tremoctopus violaceus hitchhike with jellyfishes or just their tentacles (Jones, 1963; Rosa et al., 2019, and references herein). However, as far as we know, no previous association between a benthic octopus species and gelatinous zooplankton has been published. Strugnell et al. (2004) pointed out the molecular and morphological link between the ctenoglossan holopelagic octopods of the families Amphitretidae, Bolitaenidae, and Vitreledonellidae with the deep-sea, benthic octopuses of the Antarctic genus Pareledone and the deep-water genus Graneledone, show that ctenoglossan holopelagic octopods have arisen via neoteny, from the planktonic, paralarval stages of benthic octopuses. In this way, the relatively large size of the $P$. tetracirrhus living in pelagic oceanic waters such as the individuals reported here, suggest that $P$. tetracirrhus may be considered as a model of a transitional octopus species that is colonizing the pelagic environment from the bathyal benthos by extending its juvenile and subadult stages in the water column. The connection between these young oceanic individuals with the main adult benthic population situated in muddy bottoms from the lower continental shelf and upper slope is unknown. However, the largest samples of $P$. tetracirrhus $(n=373)$, collected by means of bottom trawl by Quetglas et al. (2009), recorded the smallest individuals as having a $45 \mathrm{~mm}$ ML (larger than the pelagic specimens reported here of 25 and $33 \mathrm{~mm} \mathrm{ML}$ ) and captured small benthic individuals in deeper waters than adults, which the authors suggested was indicative of an ontogenetic migration from deep to shallower waters for $P$. tetracirrhus. It is reasonable to suspect that future investigations in the sparsely sampled mesopelagic environment may provide the necessary information to verify the life cycle of this and other bathybenthic species.

\section{DATA AVAILABILITY STATEMENT}

The raw data supporting the conclusions of this article will be made available by the authors, without undue reservation.

\section{ETHICS STATEMENT}

Ethical review and approval was not required for the animal study because the cephalopods we worked with for this study were all dead before research began. 


\section{AUTHOR CONTRIBUTIONS}

$\mathrm{RV}, \mathrm{VL}, \mathrm{MC}$, and $\mathrm{AE}$ participated in the oceanic cruises that collected the pelagic individuals. SP carried out the molecular analysis. RV, VL, and FF-Á took the morphological measurements. RV prepared the first draft. All authors contributed to the manuscript preparation and revision, and read and approved the submitted version.

\section{FUNDING}

Project funding and support was provided by the Spanish Ministry of Economy and Competitiveness (CTM201239587-C04-03, MINECO/FEDER/EU), Spanish Ministry of Science, Innovation and Universities (OCTOSET project, RTI2018-097908-B-I00, MCIU/AEI/FEDER, EU), the European Commission (SUMMER project, GA-817806) and the United Kingdom Government through the Blue Belt Programme

\section{REFERENCES}

Banas, P. T., Smith, D. E., and Biggs, D. C. (1982). An association between a pelagic octopod, argonauta sp linnaeus 1758, and aggregate salps. Fish. Bull. 80, 648-650.

Boletzky, S. V. (1981). Morphologie de l'oeuf et mode de ponte chez Pteroctopus tetracirrhus (Mollusca, Cephalopoda). Vie et Milieu 31, 255-259.

Brower, K. (1981). In Hawaii's crystal Sea a galaxy of life fills the night. Nat. Geograph. 160, 834-847.

Carrasco, S. A., Maltrain, R., Villenas, F., and Vega, M. A. (2012). New records of early life-stages of cephalopods in the Chiloe Interior Sea. Lat. Am. J. Aquat. Res. 40, 229-235. doi: 10.3856/vol40-issue1-fulltext-22

Crespi-Abril, A. C., Villanueva Gomila, G. L., Venerus, L. A., and Barón, P. J. (2014). Spatial distribution of cephalopod paralarvae in San José Gulf (Northern Patagonia, Argentina): the role of tidal circulation in larval dispersal. Fish. Res. 152, 13-20. doi: 10.1016/j.fishres.2013.07.002

Drits, A. V., Arashkevich, E. G., and Semenova, T. N. (1992). Pyrosoma atlanticum (Tunicata, Thaliacea): grazing impact on phytoplankton standing stock and role in organic carbon flux. J. Plank. Res. 14, 799-809. doi: 10.1093/plankt/14.6.799

Escánez, A., Rodríguez, S., Riera, R., Rocha, F., and Brito, A. (2019). Octopods of the Canary Islands. New records and biogeographic relationships. Moll. Res. 39, 1-12. doi: 10.1080/13235818.2018.1527970

Folmer, O., Black, M., Hoeh, W., Lutz, R., and Vrijenhoek, R. (1994). DNA primers for amplification of mitochondrial cytochrome c oxidase subunit I from diverse metazoan invertebrates. Mol. Mar. Biol. Biotechnol. 3, 294-299.

Hanlon, R. T., and Messenger, J. B. (2018). Cephalopod Behaviour. Cambridge: Cambridge University Press.

Hardwick, J. E. (1970). A note on the behavior of the octopod Ocythoe tuberculata. Cal. Fish Game 56, 68-70.

Harris, R. P., Wiebe, P. H., Lenz, J., Skjoldal, H. R., and Huntley, M. (2000). ICES Zooplankton Methodology Manual. London: Academic Press.

Henschke, N., Pakhomov, E. A., Kwong, L. E., Everett, J. D., Laiolo, L., Coghlan, A. R., et al. (2019). Large vertical migrations of Pyrosoma atlanticum play an important role in active carbon transport. J. Geophys. Res. Biogeosc. 124, 1056-1070. doi: 10.1029/2018jg004918

Jones, E. C. (1963). Tremoctopus violaceus uses Physalia tentacles as weapons. Science 139, 764-766. doi: 10.1126/science.139.3556.764

Kumar, S., Stecher, G., and Tamura, K. (2016). MEGA7: molecular evolutionary genetics analysis version 7.0 for bigger datasets. Mol. Biol. Evol. 33, 1870-1874. doi: 10.1093/molbev/msw054

Laptikhovsky, V., Salman, A., Önsoy, B., Akalin, M., and Ceylan, B. (2014). Reproduction in rare bathyal octopods Pteroctopus tetracirrhus and Scaeurgus unicirrhus (Cephalopoda: Octopoda) in the east mediterranean as an apparent (https://www.gov.uk/government/publications/the-blue-beltprogramme). FF-Á was supported by an Irish Research CouncilGovernment of Ireland Postdoctoral Fellowship Award (Ref. GOIPD/2019/460).

\section{ACKNOWLEDGMENTS}

We appreciate the help and willingness of the Biological Reference Collections of the ICM to examine $P$. tetracirrhus material and deposit the specimen ICMC000193.

\section{SUPPLEMENTARY MATERIAL}

The Supplementary Material for this article can be found online at: https://www.frontiersin.org/articles/10.3389/fmars. 2020.561125/full\#supplementary-material

response to extremely oligotrophic deep seas. Deep Sea Res. Part I: Ocean. Res. Pap. 92, 85-92. doi: 10.1016/j.dsr.2014.06.009

Lefkaditou, E., Siapatis, A., and Somarakis, S. (2005). Juvenile planktonic cephalopods sampled off the coasts of central Greece (Eastern Mediterranean) during winter. Phuket Mar. Biol. Cent. Res. Bull. 66, 259-265.

Lindley, J. A., Hernández, F., Scatllar, J., and Docoito, J. (2001). Funchalia sp. (Crustacea: Penaeidae) associated with Pyrosoma atlanticum (Thaliacea: Pyrosomidae) off the Canary Islands. J. Mar. Biol. Ass. U K. 81, 173-174. doi: 10.1017/s0025315401003551

Lo Bianco, S. (1903). Le pesche abissali eseguite da F.A. krupp col yacht puritan nelle adiacenze di Capri ed in altre localita del mediterraneo. Pubblicazione della Stazione Zoologica di Napoli 16, 109-279.

Mangold-Wirz, K. (1963). Biologie des céphalopodes benthiques et nectoniques de la mer Catalane. Vie et Milieu Supl. No. 13:285.

Norman, M. D., Finn, J. K., and Hochberg, F. G. (2014). "Family octopodidae," in Cephalopods of the World. An Annotated and Illustrated Catalogue of Cephalopod Species Known to Date, eds P. Jereb, C. F. E. Roper, M. D. Norman, and J. K. Finn (Rome: FAO Species Catalogue for Fishery Purposes), 36-215.

Okutani, T., and Osuga, K. (1986). A peculiar nesting behavior of Ocythoe tuberculata in the test of a gigantic salp. Tethys vagina. Venus 45, 67-69.

Olivar, M. P., Hulley, P. A., Castellón, A., Emelianov, M., López, C., Tuset, V. M., et al. (2017). Mesopelagic fishes across the tropical and equatorial Atlantic: biogeographical and vertical patterns. Prog. Oceanog. 151, 116-137. doi: 10. 1016/j.pocean.2016.12.001

Perissinotto, R., Mayzaud, P., Nichols, P. D., and Labat, J. P. (2007). Grazing by Pyrosoma atlanticum (Tunicata. Thaliacea) in the south Indian Ocean. Mar. Ecol. Prog. Ser. 330, 1-11. doi: 10.3354/meps330001

Quetglas, A., Ordines, F., González, M., and Franco, I. (2009). Life history of the bathyal octopus Pteroctopus tetracirrhus (Mollusca, Cephalopoda) in the Mediterranean Sea. Deep Sea Res. Part I: Oceanog Res. Pap. 56, 1379-1390. doi: 10.1016/j.dsr.2009.02.007

Rees, W. J. (1954). The macrotritopus problem. Bull. Brit. Mus. 2, 69-99.

Roper, C. F. E., Gutierrez, A., and Vecchione, M. (2015). Paralarval octopods of the florida current. J. Nat. Hist. 49, 1281-1304. doi: 10.1080/00222933.2013.802046

Roper, C. F. E., and Voss, G. L. (1983). Guidelines for taxonomic descriptions of cephalopod species. Mem. Nat. Mus. Vict. 44, 49-63.

Rosa, R., Kelly, J. T., Lopes, V. M., Paula, J. R., Gonçalves, J., Calado, R., et al. (2019). Deep-sea seven-arm octopus hijacks jellyfish in shallow waters. Mar. Biodiv. 49, 495-499. doi: 10.1007/s12526-017-0767-3

Salman, A. (2012). Two new records paralarva in the Eastern Mediterran ean (Cephalopods: Mollusca). J. Black Sea/Medit. Environm. 18, 197-207.

Strugnell, J., Norman, M., Drummond, A. J., and Cooper, A. (2004). Neotenous origins for pelagic octopuses. Curr. Biol. 14, R300-R301. 
Thiel, M., and Gutow, L. (2005). The ecology of rafting in the marine environment. II. The rafting organisms and community. Ocean. Mar. Biol. Ann. Rev. 43, 279-418. doi: 10.1201/9781420037449.ch7

Toll, R. B. (1988). The use of arm sucker number in octopodid systematics (Cephalopoda: Octopoda). Am. Malacol. Bull. 6, 207-211.

Trégouboff, G., and Rose, M. (1957). Manuel de Planctonologie Méditerranéenne, Tome 1, Texte. Paris: CNRS.

Villanueva, R., and Norman, M. D. (2008). Biology of the planktonic stages of benthic octopuses. Ocean. Mar. Biol. Ann. Rev. 46, 105-202. doi: 10.1201/ 9781420065756.ch4

Villanueva, R., Nozais, C., and Boletzky, S. V. (1997). Swimming behaviour and food searching in planktonic Octopus vulgaris cuvier from hatching to settlement. J. Exp. Mar. Biol. Ecol. 208, 169-184. doi: 10.1016/s0022-0981(96) 02670-6

Wells, M. J., Duthie, G. G., Houlihan, D. F., Smith, P. J. S., and Wells, J. (1987). Blood flow and pressure changes in exercising octopuses (Octopus vulgaris). J. Exp. Biol. 131, 175-187.
Young, R. E. (1972). The systematics and areal distribution of pelagic cephalopods from the seas off Southern California. Smith. Contr. Zool. 97, 1-159. doi: 10.5479/si.00810282.97

Young, R. E., and Harman, R. F. (1988). "Larva," "paralarva" and "subadult" in cephalopod terminology. Malacologia 29, 201-207.

Conflict of Interest: The authors declare that the research was conducted in the absence of any commercial or financial relationships that could be construed as a potential conflict of interest.

Copyright (c) 2020 Villanueva, Laptikhovsky, Piertney, Fernández-Álvarez, Collins, Ablett and Escánez. This is an open-access article distributed under the terms of the Creative Commons Attribution License (CC BY). The use, distribution or reproduction in other forums is permitted, provided the original author(s) and the copyright owner(s) are credited and that the original publication in this journal is cited, in accordance with accepted academic practice. No use, distribution or reproduction is permitted which does not comply with these terms. 